\title{
Towards an inclusive model to address unsuccessful mine closures in South Africa
}

\author{
by E.S. van Druten* and M.C. Bekker*
}

\section{Synopsis}

The complete and successful closure of a mine in the South African environment remains problematic. Closure remains an elusive mining phase due to unclear roles and responsibilities, inaccurate closure management data, and the inability of stakeholders to conceptualize and integrate closure information into business processes. Currently there are no proven methods available to address the complexities encountered during a closure application, and to date no mine has been granted full closure. Many mines are left abandoned and unrehabilitated, resulting in risk to investors, surrounding communities, and regulators. This investigation aimed to determine, categorize, and rank reasons for unsuccessful mine closures. Focus groups consisting of public and private stakeholders were identified and surveyed through a structured, rank-order questionnaire to determine the relative importance of reasons why achieving formal and final mine closure remains elusive. Various requirements and aspects were identified and listed according to four categories: namely, primary, secondary, process drivers, and information sources. These aspects should be considered in the development of an integrated mine closure model.

\section{Keywords}

mine closure, rehabilitation, planning process, integrated mine closure model.
(Brown, 2007; Nzimande and Chauke, 2012). An investigation by the Auditor General (2009) identified and listed 5906 abandoned mines as of May 2008. As of 2011 no closure certificate had been issued under the Minerals Act of 1991 or the MPRDA (Botham, 2011), and mine closure has become the focus of mining companies, governments, and nongovernmental organizations (Laurence, 2000). Formal mine closure remains an elusive undertaking presenting various risks and significant liabilities affecting investor confidence, and threatening the viability of the mining industry in South Africa.

This study was prompted by the increasing statutory pressure exerted on mines to achieve closure. It was believed that there are critical reasons for unsuccessful mine closures (van Druten, 2015). The study aimed to identify, categorize, and rank those reasons, and put forward considerations for improved mine closures.

\section{The research problem}

Successful mine closure applications remains elusive, resulting in adverse impacts on the environment, investor confidence, and the viability of the South African mining industry.

In an attempt to address the research problem the following research questions were formulated:

$>$ What are the main reasons for unsuccessful mine closure applications?

> What aspects should be considered towards the development of an integrated closure model?

Although mining presents opportunities for economic growth, it remains difficult to secure attractive investments in sustainable

* Graduate School of Technology Management, University of Pretoria, South Africa.

(C) The Southern African Institute of Mining and Metallurgy, 2017. ISSN 2225-6253. Paper received Apr. 2016; revised paper received Sep. 2016. 


\section{Towards an inclusive model to address unsuccessful mine closures in South Africa}

mining scenarios that include successful mine closure. Mine closure remains an elusive mining phase and the sector is under statutory pressure to prove its sustainability, not only through its economic contribution but also by achieving sustainable post-mining conditions. The purpose of this paper is therefore to further investigate and identify the specific reasons for unsuccessful mine closure in South Africa and to present considerations toward the development of an improved mine closure process model.

\section{Literature review}

The closure and rehabilitation of a mine entails a formal, approved programme to restore the physical, chemical, and biological quality of air, land, and water where mining took place (Australian and New Zealand Minerals and Energy Council, 2000). Mine closure forms part of the mine's longterm planning (Kloppers, Horn, and Visser, 2015) and aims towards the creation of sustainable living outcomes through the minimization of environmental, social, and economic impacts on host communities once mining has ceased (Logan, Murphy, and Beale, 2007). The process of mine closure occurs at the point where the development and revenue costs of the mining operation approach zero value and the remediation cost becomes evident (Turton, 2008). Unfortunately, the closure of a mine is a complex process that is influenced by a variety of political, social, economic, and technical factors that need to be balanced to ensure a successful mine closure application. Due to the disruptive nature of mining it has become synonymous with adverse environmental and social effects. Adverse environmental effects are manifest particularly in surface and groundwater systems, pollution of agricultural soil, air pollution, sinkholes due to the accelerated weathering of dolomites by acid minewater, unsafe living conditions in adjacent communities, dust generation, and the destruction of ecosystems (Auditor General, 2009).

The reasons reported for unsuccessful closure are numerous, and are often associated with organizational and stakeholder interaction, poor scope definition and planning, unclear relinquishment criteria, legal and financial constraints, and social, scientific, or environmental concerns.

Hordley (cited in Australian and New Zealand Minerals and Energy Council, 2000, p. 6) describes closure as 'the converse of closure skill levels, operational experience, motivation and commitment'. Mine closure necessitates specialist and administrative skills and input at national, provincial, and local levels. According to Mhlongo and Amponsah-Dacosta (2016, p. 279) the lack of clear assigned responsibilities as well as the absence of criteria and standards for rehabilitation are major causes for delays in rehabilitation. Van Eeden, Lieferink, and du Rand (2009 p. 52 ) agree with the multidisciplinary requirement and stress the importance of addressing differences of interpretation between government and the MRH. Du Plessis (n.d.) contextualizes the responsibilities created by a mine closure application through the Constitution at national, provincial, and local levels which leads to misalignment among the hierarchical reporting structures. This results in all three spheres of government being 'distinctive, interdependent and interrelated', and all of them have environmental responsibilities during a closure application. Adding to the dilemma of closure, there seems to be no clear and widely accepted definition of abandoned mines (Mhlongo, 2012).

The disparity among stakeholders representing statutory institutions and subsequent delays in decision-making and progress results in defensive behaviour from MRHs. Adler et al., (2007, p. 36) argue that mining companies have held production costs artificially low, deflecting rehabilitation costs to the State and third parties.

Integrated mine closure planning (IMCP) requires closure planning and execution to start prior to the commencement of physical mining activities and continue until final closure of a mining operation. Unfortunately, the planning process is often fast-tracked, causing some technical and statutory aspects to be omitted during the early phases and then to be re-addressed and compensated for during the closing phases of the project life-cycle (Anglo American, 2013). The Government of Western Australia (GWA) (2011, p. 3) reflects a similar stance and reports that planning for mine closure should start before mining commences and continue throughout the life of the mine until final closure is achieved.

The International Council on Mining and Metals (ICMM, 2006, p. 5) recognizes the responsibilities of the MRH during closure. The responsibilities shall include the provision of adequate financial resources, definition of a clear mining closure process, and ensuring that the public is not left with a liability.

Du Plessis (n.d.) recognized the existence of mine closure functions in law, emphasizing that government officials are often unwilling to cooperate. He reports that the fragmentation of departments dealing with different aspects of the environment results in uncoordinated application of environmental legislation. The accompanying lack of skills and funds compounds the poor effort towards the mine closure process.

Dual responsibilities towards mine activities remains a recurring dilemma. Even as far back as 1998 the Department of Environmental Affairs and Tourism (DEAT) was the designated competent authority for Environmental Impact Assessment (EIA) authorization. The Department of Minerals and Energy (DME) was, however, the competent authority for mining projects. This dual approach to EIA is mentioned as a major contributor to delays in closure activities (Sandham, Hoffmann, and Retief, 2008).

Financial assurances for eventual mine closure are required by section 41 of the MPRDA and implemented through the Department of Mineral Resources (DMR) financial provision guideline (2005). The MRH is therefore required to determine the closure obligation and report a financial provision to the DMR. The accuracy of the provision is often questioned due to inaccurate assessments, shortfalls, over-provisions, and inconsistent regulatory expectations.

IMCP is exemplified by integrating mine closure requirements into core business, legal, operational, and relevant external processes instead of relying on retrofitted closure plans. The intent is that IMCP should consequently offer improved stakeholder and regulatory interaction and have a positive influence on concurrent rehabilitation planning and execution (Limpitlaw and Briel, 2014). It is notably a concept omitted as a mine closure principle from sections 56 and 57 of the MPRDA, creating uncertainty of its relevancy and consequently being overlooked by stakeholders. 


\section{Towards an inclusive model to address unsuccessful mine closures in South Africa}

Environmental and social closure outcomes rely on the accuracy of scientific and social indicator data, as well as the ability of stakeholders to conceptualize data to produce effective closure objectives and relinquishment criteria. This is often hampered by vague directives in the MPRDA, highly complex environmental aspects during closure, unpredictability of post-closure impacts, inconsistent, inaccurate closure performance reviews, and an inability to secure stakeholder inputs on closure requirements. Despite all the shortcomings, it remains important to approach any form of rehabilitation in a structured manner and identify commonly agreed key performance areas (Dougall and Mmola, 2015, 1003).

\section{Research design}

In summarizing the literature findings, the reasons for mine closure failure can be clustered in seven categories: organiza- tional, planning, relinquishment, legal, financial, social, and scientific, which also addresses the environmental influences. A total of 37 possible causes for unsuccessful mine closure were identified and allocated to the appropriate categories (see Table I). It was also evident from the literature that the poor record of mine closure was predominately due to the actions, or lack thereof, of direct role-players from formal institutions as opposed to wider society.

In order to assess the influence of the identified reasons on the poor performance of mine closure, six focus groups (FGs) comprising 31 individual representatives were identified from various stakeholders involved in mine closure efforts. The six FGs were national regulators (NR), educational research facilities (ERF), consultants (C), nongovernmental organizations (NGO), mine management (MM), and environmental legal specialists (LSpec). The C group comprised three subgroups, namely engineering

Table I

Reasons for unsuccessful mine closure per category

\begin{tabular}{|c|c|c|}
\hline \multicolumn{2}{|l|}{ Number } & \multirow{2}{*}{$\begin{array}{c}\text { Reason } \\
\text { Disengagement among regulators and stakeholders }\end{array}$} \\
\hline A: Organizational & A1 & \\
\hline & A2 & Unclear roles and responsibilities of regulators and stakeholders \\
\hline & A3 & Shortage of relevant skills and knowledge with regulators \\
\hline & A4 & Lack of a dedicated MCPT \\
\hline & A5 & Lack of qualified and experienced mine closure auditors \\
\hline \multirow[t]{6}{*}{ B: Planning } & B1 & Lack of closure planning and integration during feasibility stages \\
\hline & B2 & Mine closure requirements not included in operational processes \\
\hline & B3 & Lack of concurrent rehabilitation planning \\
\hline & B4 & Non-alignment of closure plans with local or regional spatial development plans \\
\hline & B5 & Non-responsiveness to changing closure requirements over time \\
\hline & B6 & Regulator and stakeholder disregard of IMCP practices \\
\hline \multirow[t]{5}{*}{ C: Relinquishment } & $\mathrm{C} 1$ & Deficient post-closure risk assessment reports \\
\hline & $\mathrm{C} 2$ & Inaccurate social relinquishment criteria \\
\hline & $\mathrm{C3}$ & Inaccurate environmental relinquishment criteria \\
\hline & $\mathrm{C} 4$ & Inaccurate aesthetical relinquishment criteria \\
\hline & $\mathrm{C} 5$ & Inaccurate land use relinquishment criteria \\
\hline \multirow[t]{6}{*}{ D: Legal } & D1 & Overlapping and contradicting regulatory mandates \\
\hline & $\mathrm{D} 2$ & Inaccurate financial provisions (MPRDA Section 41 (1)) \\
\hline & D3 & Lack of DWS and DMR interaction on closure approvals (MPRDA Section 43 (5)) \\
\hline & D4 & Incomplete closure applications (MPRDA Section 43 (4): I) \\
\hline & D5 & Nonspecific environmental objectives approved in EMP's (MPRDAR 51 (a) i) \\
\hline & D6 & Incorrect itemization of closure items (MPRDA Regulations 54 (1)) \\
\hline \multirow[t]{5}{*}{ E: Financial } & E1 & Lack of internalized financial provisions \\
\hline & E2 & Lack of accurate and comprehensive financial liability assessments \\
\hline & E3 & Non standardized methods and mechanisms for financial provision \\
\hline & E4 & Unrealistic regulatory closure provision requirements \\
\hline & E5 & Inaccessibility of funds during closure \\
\hline \multirow[t]{5}{*}{ F: Social } & $\mathrm{F} 1$ & Uncertainty of health risks around un-rehabilitated mining areas \\
\hline & F2 & Agricultural potential of land and social structures \\
\hline & F3 & Ineffective conceptualization of social issues toward closure \\
\hline & F4 & Ineffective social interaction when establishing closure objectives \\
\hline & F5 & Understated social considerations during closure \\
\hline \multirow[t]{5}{*}{ G: Scientific } & G1 & Incorrect quantification of lasting environmental impacts (MPRDA Regulations 56 (d)) \\
\hline & G2 & Incorrect quantification of latent environmental impacts (MPRDA Regulations 56 (d)) \\
\hline & G3 & Insufficient internal skillset required to conceptualize scientific results \\
\hline & G4 & Absence of an ongoing closure performance auditing and reporting plan \\
\hline & G5 & Lack of effective interaction between scientists during closure planning \\
\hline
\end{tabular}




\section{Towards an inclusive model to address unsuccessful mine closures in South Africa}

consultants (CEng), environmental consultants (CE), and social consultants (CS). The MM group comprised four subgroups, namely safety, health, environmental, and quality managers (MMSHEQ), environmental managers (MME), operational managers (MMOPS), and strategic managers (MMStrat). The overall profile of the complete FG is presented in Table II.

To determine the relative importance of an identified reason for unsuccessful mine closures, a rank order approach was adopted. A questionnaire was compiled requesting the FG members to rank the various contributing reason per category. The most important contributing reason to their view was to be ranked ' 1 ', second most important reason as ' 2 ', and the least important reason ' 5 ' or ' 6 ', depending on the category ranked. An average rank for each categorized reason per $\mathrm{FG}$ was determined by averaging the individual rankings of the FG respondents in that group (Table III).
Table II

Composition of the focus group

\begin{tabular}{|l|c|c|c|}
\hline Number & Description & Abbreviation & Members \\
\hline 1 & National Regulator & NR & 2 \\
2 & Educational research facility & ERF & 3 \\
3 & Consultants & C & 9 \\
3.1 & Engineering consultants & CEng & 3 \\
3.2 & Environmental consultants & CE & 3 \\
3.3 & Social consultants & CS & 3 \\
4 & Non-governmental organizations & NGO & 2 \\
5 & Mine management & MM & 12 \\
5.1 & SHEQ & MMSHEQ & 2 \\
5.2 & Environmental & MME & 4 \\
5.3 & Operational & MMOPS & 3 \\
5.4 & Strategic & LSpec & 3 \\
6 & Legal specialists & & \\
\hline Total & 31 & & \\
\hline
\end{tabular}

Table III

Ranked reasons per FG stakeholder group

\begin{tabular}{|c|c|c|c|c|c|c|c|c|c|c|c|c|c|c|c|}
\hline \multirow[t]{3}{*}{ Category } & \multirow[t]{3}{*}{ Reason } & \multicolumn{14}{|c|}{ Focus Group } \\
\hline & & \multicolumn{2}{|c|}{ NR } & \multicolumn{2}{|c|}{ ERF } & \multicolumn{2}{|c|}{ C } & \multicolumn{2}{|c|}{ NGO } & \multicolumn{2}{|c|}{ MM } & \multicolumn{2}{|c|}{ LSpec } & \multicolumn{2}{|c|}{ Overall } \\
\hline & & Av & $\mathbf{R}$ & Av & $\mathbf{R}$ & Av & $\mathbf{R}$ & Av & $\mathbf{R}$ & Av & $\mathbf{R}$ & Av & $\mathbf{R}$ & Av & Rank \\
\hline \multirow[t]{5}{*}{ A: Organizational } & $\mathrm{A} 1$ & 3.50 & 3 & 4.00 & 4 & 3.22 & 3 & 3.50 & 3 & 2.02 & 1 & 3.00 & 3 & 3.21 & 3 \\
\hline & $\mathrm{A} 2$ & 3.00 & 2 & 4.67 & 5 & 3.11 & 2 & 2.50 & 1 & 3.06 & 4 & 4.00 & 5 & 3.39 & 5 \\
\hline & A3 & 1.00 & 1 & 2.67 & 3 & 2.78 & 1 & 3.00 & 2 & 3.04 & 3 & 1.67 & 1 & 2.36 & 1 \\
\hline & A4 & 4.00 & 4 & 2.00 & 2 & 3.11 & 2 & 2.50 & 1 & 2.71 & 2 & 2.67 & 2 & 2.83 & 2 \\
\hline & A5 & 3.50 & 3 & 1.67 & 1 & 2.78 & 1 & 3.50 & 3 & 4.17 & 5 & 3.67 & 4 & 3.21 & 4 \\
\hline \multirow[t]{6}{*}{ B: Planning } & B1 & 4.50 & 4 & 2.33 & 2 & 2.22 & 1 & 3.00 & 2 & 3.04 & 2 & 1.33 & 1 & 2.74 & 1 \\
\hline & B2 & 3.50 & 3 & 2.00 & 1 & 3.33 & 4 & 3.00 & 2 & 2.54 & 1 & 4.33 & 4 & 3.12 & 2 \\
\hline & B3 & 3.00 & 2 & 4.00 & 4 & 2.78 & 2 & 4.00 & 3 & 3.10 & 3 & 4.00 & 3 & 3.48 & 4 \\
\hline & B4 & 1.50 & 1 & 5.33 & 5 & 3.22 & 3 & 4.50 & 4 & 4.42 & 6 & 4.00 & 3 & 3.83 & 5 \\
\hline & B5 & 3.50 & 3 & 4.00 & 4 & 4.56 & 5 & 2.50 & 1 & 4.00 & 5 & 1.67 & 2 & 3.37 & 3 \\
\hline & B6 & 5.00 & 5 & 3.33 & 3 & 4.89 & 6 & 4.00 & 3 & 3.9 & 4 & 5.67 & 5 & 4.46 & 6 \\
\hline \multirow[t]{5}{*}{ C: Relinquishment } & $\mathrm{C} 1$ & 2.00 & 1 & 3.00 & 2 & 1.67 & 1 & 2.00 & 1 & 2.83 & 4 & 2.67 & 3 & 2.36 & 1 \\
\hline & $\mathrm{C} 2$ & 2.00 & 1 & 3.67 & 3 & 3.89 & 4 & 3.00 & 3 & 2.67 & 3 & 2.33 & 2 & 2.93 & 4 \\
\hline & $\mathrm{C} 3$ & 4.50 & 2 & 2.00 & 1 & 2.56 & 2 & 2.50 & 2 & 2.48 & 1 & 1.67 & 1 & 2.62 & 3 \\
\hline & $\mathrm{C} 4$ & 4.50 & 2 & 4.33 & 4 & 4.11 & 5 & 5.00 & 4 & 4.4 & 5 & 5.00 & 5 & 4.56 & 5 \\
\hline & $\mathrm{C} 5$ & 2.00 & 1 & 2.00 & 1 & 2.78 & 3 & 2.50 & 2 & 2.63 & 2 & 3.33 & 4 & 2.54 & 2 \\
\hline \multirow[t]{6}{*}{ D: Legal } & D1 & 3.00 & 3 & 4.33 & 5 & 3.11 & 2 & 1.00 & 1 & 2.42 & 1 & 1.00 & 1 & 2.48 & 2 \\
\hline & D2 & 2.00 & 1 & 1.67 & 1 & 3.44 & 3 & 4.50 & 4 & 2.46 & 2 & 4.00 & 3 & 3.01 & 3 \\
\hline & D3 & 2.50 & 2 & 3.00 & 2 & 2.44 & 1 & 2.00 & 2 & 2.48 & 3 & 2.00 & 2 & 2.40 & 1 \\
\hline & D4 & 5.50 & 6 & 4.67 & 6 & 3.78 & 4 & 4.50 & 5 & 4.75 & 5 & 4.33 & 4 & 4.59 & 5 \\
\hline & D5 & 3.50 & 4 & 3.33 & 3 & 3.78 & 4 & 3.00 & 3 & 3.77 & 4 & 4.00 & 3 & 3.56 & 4 \\
\hline & D6 & 4.50 & 5 & 4.00 & 4 & 4.44 & 5 & 6.00 & 6 & 5.13 & 6 & 5.67 & 5 & 4.96 & 6 \\
\hline \multirow[t]{5}{*}{ E: Financial } & E1 & 5.00 & 4 & 1.33 & 1 & 3.00 & 3 & 3.00 & 2 & 3.4 & 4 & 4.67 & 4 & 3.4 & 4 \\
\hline & E2 & 3.00 & 3 & 2.00 & 2 & 2.56 & 2 & 3.00 & 2 & 2.71 & 2 & 2.67 & 2 & 2.66 & 2 \\
\hline & E3 & 3.00 & 3 & 4.67 & 5 & 3.56 & 4 & 4.00 & 3 & 3.42 & 5 & 2.33 & 1 & 3.5 & 5 \\
\hline & E4 & 2.50 & 2 & 4.00 & 4 & 2.33 & 1 & 2.00 & 1 & 2.63 & 1 & 2.33 & 1 & 2.63 & 1 \\
\hline & E5 & 1.50 & 1 & 3.00 & 3 & 3.56 & 4 & 3.00 & 2 & 2.85 & 3 & 3.00 & 3 & 2.82 & 3 \\
\hline \multirow[t]{5}{*}{ F: Social } & $\mathrm{F} 1$ & 4.50 & 4 & 4.67 & 4 & 2.67 & 1 & 4.00 & 2 & 4.31 & 5 & 3.67 & 4 & 3.97 & 5 \\
\hline & $\mathrm{F} 2$ & 4.50 & 4 & 3.00 & 3 & 3.33 & 3 & 5.00 & 3 & 3.88 & 4 & 3.33 & 3 & 3.84 & 4 \\
\hline & F3 & 2.00 & 2 & 2.67 & 2 & 2.78 & 2 & 2.00 & 1 & 2.33 & 2 & 3.67 & 4 & 2.57 & 2 \\
\hline & $\mathrm{F} 4$ & 1.50 & 1 & 2.00 & 1 & 2.67 & 1 & 2.00 & 1 & 1.9 & 1 & 2.00 & 1 & 2.01 & 1 \\
\hline & F5 & 2.50 & 3 & 2.67 & 2 & 3.56 & 4 & 2.00 & 1 & 2.58 & 3 & 2.33 & 2 & 2.61 & 3 \\
\hline \multirow[t]{5}{*}{ G: Scientific } & G1 & 3.50 & 3 & 2.67 & 2 & 2.33 & 1 & 2.50 & 2 & 2.23 & 1 & 1.67 & 1 & 2.48 & 1 \\
\hline & G2 & 3.50 & 3 & 2.67 & 2 & 2.89 & 3 & 4.00 & 4 & 3.15 & 4 & 2.67 & 2 & 3.5 & 3 \\
\hline & G3 & 3.00 & 2 & 3.67 & 3 & 3.78 & 5 & 3.00 & 3 & 2.96 & 3 & 4.00 & 5 & 3.40 & 5 \\
\hline & G4 & 3.00 & 2 & 1.00 & 1 & 2.44 & 2 & 4.00 & 4 & 2.92 & 2 & 3.00 & 3 & 2.73 & 2 \\
\hline & G5 & 2.00 & 1 & 5.00 & 4 & 3.56 & 4 & 1.50 & 1 & 3.75 & 5 & 3.67 & 4 & 3.25 & 4 \\
\hline
\end{tabular}




\section{Towards an inclusive model to address unsuccessful mine closures in South Africa}

\section{Results}

A fair level of agreement among the FGs were observed regarding the relative importance of the various reasons for unsuccessful mine closure, especially with respect to the top three reasons under each category.

Under category A (Organizational), all six FGs ranked 'Shortage of relevant mine closure skills and knowledge within the regulator' among the top three reasons. Even though 'Lack of qualified and experienced mine closure auditors' scored the highest rank (lowest influence), it was ranked by $\mathrm{C}$ (rank 2) and NGO (rank 1) as significant. This could be a result of these FGs believing that once their work is completed, auditing of the closure process is not completed satisfactorily. Apart from NR (rank 4), all other FGs ranked 'Lack of a dedicated mine closure project management team (MCPT)' high with either rank 1 or rank 2.

In order to improve organizational effectiveness towards mine closure, the level of skills within the regulator needs to be addressed as well as the mobilization of dedicated project teams.

Apart from NR (ranked 4) 'Lack of closure planning during feasibility stages' was ranked the most, or second most, important reason under category B (Planning). The reason could be that the NR is not integrally involved during the feasibility stages of the project. It is interesting to note that the NR group viewed 'Non-alignment of closure plans with the regional spatial development plans' as the most important reason, whereas the overall rank for this reason is 5. In recognition of the importance of planning, the overall rank for 'Regulatory disregard for IMCP practices' was the lowest (6).

Under category C (Relinquishment), 'Deficient post closure risk assessment reports' and 'Inaccurate land use relinquishment criteria' appear to be the most significant reasons for unsuccessful mine closure.

The dual-responsibility dilemma and fragmentation among statutory bodies (du Plessis, n.d.) was emphasized under category D (Legal). 'Lack of interaction between Department of Water Affairs (DWA) and DMR on closure approvals in accordance with MPRDA Section 43 (5)' and 'Overlapping and contradicting regulatory mandates' were strongly regarded by the majority of FGs as the key reasons for failure. This disparity is an institutional problem that needs government intervention to resolve towards a single point of responsibility.

It is significant that 'Incorrect itemization of closure items required by the MPRDA Regulations 54 (1)' was not deemed an important reason for failure, indicating that role-players do comply with statutory formalities. The process seems to halt at decision-making activities.

Under category E (Financial) no significant reason was identified as a distinct contributor to failure. The average rating scores were fairly close, with 'Unrealistic regulatory closure provision requirements' rating first and 'The lack of accurate and comprehensive financial liability assessments' a close second. The provision of financial resources is accepted by stakeholders and it is believed that most will adhere to the provision requirements.

All participating FGs agreed that 'Ineffective social interaction when establishing closure' was the main reason for failure under category $F$ (Social). The knowledge and awareness of stakeholder regarding the health risks around unrehabilitated areas were confirmed with 'The uncertainty of health risks around un-rehabilitated mining areas' regarded as the least significant reason for failure.

Under category $\mathrm{G}$ (Scientific), a general consensus is observed among FGs that 'The incorrect quantification of lasting environmental impacts (MPRDA Regulations 56 (d))' is the most significant reason for unsuccessful mine closure. This could be due to the lack of extended historical data on the long-term impact of rehabilitation. The fact that 'The insufficient internal skillset required to conceptualize scientific results' was considered as the least significant reason for failure indicates that the FG stakeholders acknowledge that skilled scientists put effort into better understanding the rehabilitation of mining areas.

\section{Conclusions}

The formal and successful closure of depleted mining complexes remains an elusive goal. Through a literature study of the poor performance of this final stage of the mining life-cycle, 37 potential contributing reasons for failure were identified and clustered into seven categories. A total of 31 stakeholders in the mine closure process were identified and clustered in six FGs. A ranking questionnaire was circulated to the various stakeholders and their feedback was analysed.

The categorized ranking quantified the reasons for consideration toward improved mine closure, while the comparison amongst the FGs confirmed specific opinions and expectations.

It was commonly agreed that the lack of skills and dedicated project teams were significant contributors to poor performance, and therefore a formal and concerted effort should be launched to train and educate stakeholders. Lack of planning during the feasibility stages was a contributing factor, while deficient post-closure risk assessment reports and inaccurate land use relinquishment criteria were also mentioned. Institutional uncertainties and dual responsibilities paralyse decision-making at top management level, thereby effectively halting any form of progress. Government intervention is urgently required to address the current fragmentation among government departments. Insufficient financial provision does not seem to be a major contributing factor. However, ineffective social interaction when establishing closure objectives appears to be the most agreed upon reason for social failure among FGs. A concerted effort should be launched to communicate to stakeholders, especially those physically and financially affected, regarding the process and impact of mine closure on their livelihood.

Scientifically, it seems as if experts are doing what they can; however, the long-term process and effects of mine rehabilitation are still unknown.

Given the findings of the research, an integrated mine closure model is proposed.

\section{Recommendations}

An integrated mine closure model should aim to include all the aspects that could influence the closure process. Such a model should structure all the data, information, processes, activities, deliverables, interactions, and decisions required for successful mine closure. Based on the findings in this research, four categories of aspects were identified that should be considered towards the development of an allinclusive mine closure model. 


\section{Towards an inclusive model to address unsuccessful mine closures in South Africa}

Firstly, five primary considerations (PC), and four secondary considerations (SC) were identified as most important regarding successful mine closure. These considerations are shown in Table IV.

Secondly, the combined ranking and comparison results highlighted critical closure process drivers (PD) and information sources (IS) that are required to inform and contextualize the PC and SC during closure planning. Table V depicts these PD and IS requirements for improved mine closures.

When considering a mine closure model it will be advisable to integrate the PC, SC, PD, and IS aspects. This model should complement the overall life-cycle management (LCM) of the mine and provide a real-time reference to the

Table IV

\section{Primary and secondary considerations for improved mine closure applications}

\begin{tabular}{|l|l|}
\hline \multicolumn{1}{|c|}{ Primary considerations (PC) } \\
\hline PC 1 & $\begin{array}{l}\text { Availability of accurate closure management data and } \\
\text { information } \\
\text { Competence of the stakeholders and the regulator to concep- } \\
\text { tualize data and information } \\
\text { Ability of organizations to integrate mine closure } \\
\text { requirements into various business processes } \\
\text { PC 3location of definitive roles and responsibilities to all } \\
\text { stakeholders and regulatory institutions } \\
\text { Pndorsement of mine closure planning through a dedicated } \\
\text { project management structure }\end{array}$ \\
PC 5 & \multicolumn{1}{|c|}{ Secondary considerations (SC) } \\
\hline SC 1 & $\begin{array}{l}\text { Accurate mine closure objectives and targets } \\
\text { Qualified mine closure auditors and auditing programmes } \\
\text { Elevated levels of skill and knowledge of the stakeholders } \\
\text { SC 3volved } \\
\text { Clear and communicated functional tasks of the stakeholders }\end{array}$ \\
SC 4 & Clear and \\
\hline
\end{tabular}

\section{Table $\mathrm{V}$}

Process drivers and information sources for improved mine closure applications

\begin{tabular}{|c|c|}
\hline \multicolumn{2}{|r|}{ Process drivers (PD) } \\
\hline $\begin{array}{l}\text { PD } 1 \\
\text { PD } 2 \\
\text { PD } 3 \\
\text { PD } 4 \\
\text { PD } 5 \\
\text { PD } 6 \\
\text { PD } 7 \\
\text { PD } 8\end{array}$ & $\begin{array}{l}\text { Social interventions during closure planning } \\
\text { Inter-scientist communication during closure planning } \\
\text { Long-term impact identification } \\
\text { Consideration to changing environmental conditions } \\
\text { Ongoing concurrent rehabilitation planning and reviews } \\
\text { Ongoing regulator dexterity development initiatives } \\
\text { Clear legal compliance requirements } \\
\text { Effective cooperative governance amongst stakeholders }\end{array}$ \\
\hline \multicolumn{2}{|r|}{ Information sources (IS) } \\
\hline $\begin{array}{l}\text { IS } 1 \\
\text { IS } 2 \\
\text { IS } 3 \\
\text { IS } 4 \\
\text { IS } 5 \\
\text { IS } 6 \\
\text { IS } 7 \\
\text { IS } 8 \\
\text { IS } 9 \\
\text { IS } 10 \\
\text { IS } 11 \\
\text { IS } 12\end{array}$ & $\begin{array}{l}\text { Social abandonment criteria } \\
\text { Land use abandonment criteria } \\
\text { Environmental abandonment criteria } \\
\text { Closure risk assessment report } \\
\text { Closure liability assessment } \\
\text { Closure performance audit } \\
\text { Feasibility planning document } \\
\text { Organization procedures and processes } \\
\text { Regional spatial development programmes } \\
\text { Job description of the mining right holder } \\
\text { Job descriptions of other stakeholders } \\
\text { Job description of the regulators }\end{array}$ \\
\hline
\end{tabular}

mining phase and the immediate and future rehabilitation liability while securing closure expectations from the regulator, the MRH, and other stakeholder groups.

\section{References}

Adler, R.A., Claassen, M., Godfrey, L., and Turton, A.R. 2007. Water, mining, and waste: An historical and economic perspective on conflict management in South Africa. Economics of Peace and Security Journal, vol. 2, no. 2. pp.33-41

Anglo AmericAn. 2013. Mine closure toolbox version 2. Anglo American plc. Johannesburg, South Africa

Auditor GenERAL. 2009. Report to Parliament on a performance audit of the rehabilitation of abandoned mines at the Department of Minerals and Energy. Pretoria, South Africa.

Australian and New Zealand Minerals and Energy Council. 2000. Strategic framework for mine closure. Report no. ISR 2000/155. Minerals Council of Australia, Canberra, Australia.

BoтнAм, N.D. 2011. A critical analysis of the mine closure process as followed by the De Beers Oaks diamond mine. MSc thesis, University of Johannesburg, South Africa.

Brown, J. 2007. Derelict mines to cost state R100bn. Business Report, 23 May 2007. p 22

Chamber of Mines of South Africa. 2007. Guidelines for the rehabilitation of mined land. Chamber of Mines of South Africa, Coaltech Research Association, Johannesburg.

Dougall, A.W. and MmoLA, T.M. 2015, Identification of key performance areas in the Southern Africa surface mining delivery environment. Journal of the Southern African Institute of Mining and Metallurgy, vol. 115 pp. 1001-1006.

Du Plessis, A. and Brent, A.C. 2006. Development of a risk-based mine closure cost calculation model. Journal of the South African Institute of Mining and Metallurgy, vol. 106. pp. 443-450.

Du PLESSIS, M. Not dated. Legal mechanisms for cooperative governance in South Africa: successes and failures. LLB dissertation, University of Cape Town.

Government of Western Australia (GWA). 2011. Guidelines for preparing mine closure plans. Government of Western Australia, Environmental Protection Authority. Australia.

ICMM (International Council on Mining and Metals). 2006. Guidance paper for financial assurance for mine closure and reclamation. London, UK.

ICMM (International Council on Mining and Metals). 2008. Planning for integrated mine closure: toolkit. London, UK.

KLOPPERS, B.J., HoRn, C.J., and VisSER, J.V.Z. 2015. Strategic and tactical requirements of a mining long-term plan. Journal of the Southern African Institute of Mining and Metallurgy, vol. 115. pp. 515-521.

Logan, R.B., MuRPhy, D.P., and BeALE, C.A. Mine closure risk and decision analysis. Proceedings of the Second International Seminar on Mine Closure, Brisbane, Australia. pp. 1-2.

LAURENCE, D.C. 2000. Optimisation of the mine closure process. Journal of Cleaner Production, vol. 14. pp. 285-298.

LimpitLAW, D. and BRIEL, A. 2014. Post-mining land use opportunities in developing countries - a review. Journal of the Southern African Institute of Mining and Metallurgy, vol. 114. pp. 899-903.

MHLongo, S.E. 2012. Development of a modeling framework for design of lowcost and appropriate rehabilitation strategies for Nyala abandoned mine. MSc dissertation, Department of Mining and Environmental Geology, University of Venda, South Africa.

Mhlongo, S.E. and Amponsah-Dacosta, F. 2016, A review of problems and solutions of abandoned mines in South Africa. International Journal of Mining, Reclamation and Environment, vol. 30, no. 4. pp. 279-294.

NzimANDE, Z. and CHAuKe, H. 2012, Sustainable through responsible environmental mining. Journal of the Southern African Institute of Mining and Metallurgy, vol. 112. pp. 135-139.

Sandham, L.A. Hoffmann, A.R., and Retief, F.P. 2008. Reflections on the quality of mining EIA reports in South Africa. Journal of the Southern African Institute of Mining and Metallurgy, vol. 108. pp. 701-706.

SoutH AFricA. Mineral and Petroleum Resources Development Act 28 of 2002. Government Printer, Pretoria.

SwART, E. 2003. The South African legislative framework for mine closure Journal of the South African Institute of Mining and Metallurgy, vol. 10. pp. 45-54.

TURTON, R.A. 2008. Water and mine closure in South Africa: development that is sustainable? On-line dialogue: Development 2008 'Water and Development'. CSIR, Pretoria. http://www.researchgate.net/publication/242598362_Water_and_Mine_C osure in South_Africa_Development that is sustainable

VAN EEDEN, E.S., LIEFERINK, M., and Du RAND, J.F. 2009. Legal issues concerning mine closure and social responsibility on the West Rand. Journal for Transdisciplinary Research in Southern Africa, vol. 5, no. 1. pp. 51-71.

VAN DRUTEN, E. 2015. A critical analysis of reasons for unsuccessful mine closures in South Africa. MSc thesis, Department of Engineering and Technology Management, University of Pretoria, South Africa. 